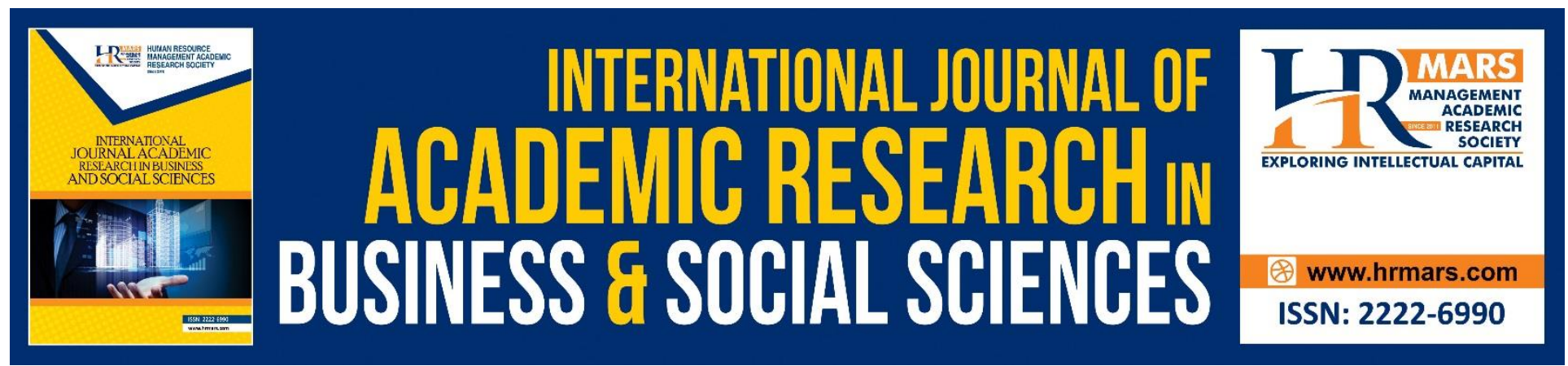

\title{
The Impact of Authentic Leadership in the OCB and Employees Commitment in the Jordanian Companies
}

Ghassan Issa Alomari, Malek Alharafsheh, Muhmmad I Nofal

To Link this Article: http://dx.doi.org/10.6007/IJARBSS/v9-i11/6565

DOI: 10.6007/IJARBSS/v9-i11/6565

Received: 12 October 2019, Revised: 30 October 2019, Accepted: 08 November 2019

Published Online: 04 December 2019

In-Text Citation: (Alomari, Alharafsheh, \& Nofal 2019)

To Cite this Article: Alomari, G. I., Alharafsheh, M. I., Nofal, M. I. (2019). The Impact of Authentic Leadership in the OCB and Employees Commitment in the Jordanian Companies. International Journal of Academic Research in Business and Social Sciences, 9(11), 437-458.

Copyright: (C) 2019 The Author(s)

Published by Human Resource Management Academic Research Society (www.hrmars.com)

This article is published under the Creative Commons Attribution (CC BY 4.0) license. Anyone may reproduce, distribute, translate and create derivative works of this article (for both commercial and non-commercial purposes), subject to full attribution to the original publication and authors. The full terms of this license may be seen at: http://creativecommons.org/licences/by/4.0/legalcode

Vol. 9, No. 11, 2019, Pg. 437 - 458

http://hrmars.com/index.php/pages/detail/IJARBSS

JOURNAL HOMEPAGE

Full Terms \& Conditions of access and use can be found at http://hrmars.com/index.php/pages/detail/publication-ethics 


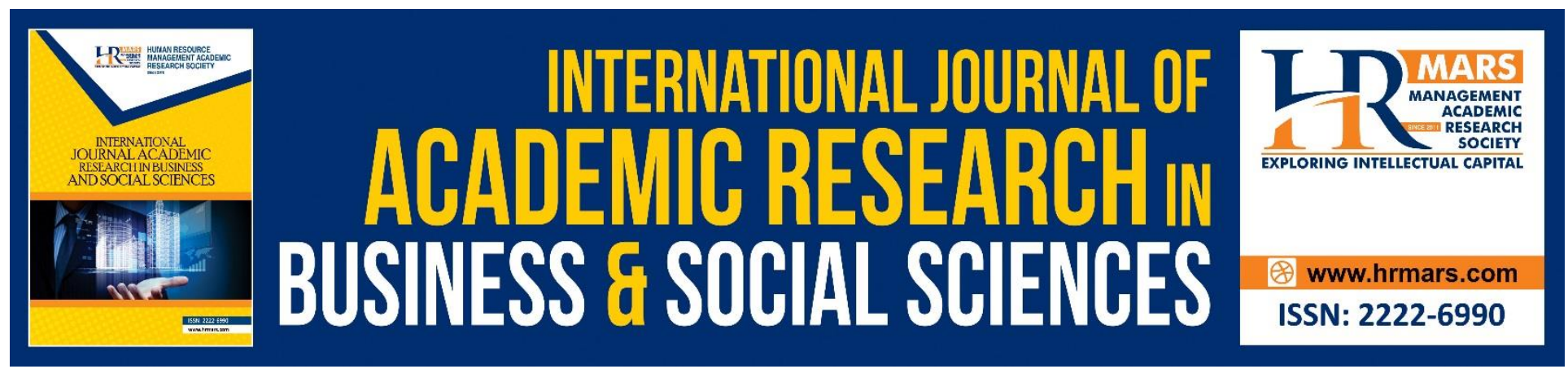

\title{
The Impact of Authentic Leadership in the OCB and Employees Commitment in the Jordanian Companies
}

\author{
${ }^{1}$ Ghassan Issa Alomari, ${ }^{2}$ Malek Ibrahim Alharafsheh, ${ }^{3}$ Muhmmad I \\ Nofal \\ ${ }^{1+2}$ College of Business, Amman Arab University, Jordan Street-Mubis, ${ }^{3}$ College of Business, Al- \\ Ahliyya Amman University, Amman 11953 - Jordan \\ Email: ghassanomari@aau.edu.jo,2alserhan@aau.edu.jo,3mh.nofal@gmail.com
}

\begin{abstract}
The study aimed to measure the impact of authentic leadership in organizational citizenship behavior and organizational commitment in Jordanian Companies. Six companies operating in different sectors were selected. Sample unit consist 31 employees. Questionnaire designed to collect data with 5 Likert Scale, Statistical analysis was performed descriptive using the arithmetic mean, Standard deviation. The results show high levels of organizational citizenship behavior and medium levels of authentic leadership and organizational commitment. The results of the Simple regression analysis were existence the impact statistically significant of Authentic leadership in organizational citizenship behavior and organizational commitment among workers in companies. The impact statistically significant authentic leadership in organizational citizenship behavior greatest degree than organizational commitment, and the Impact statistically significant Authentic leadership in organizational commitment. This research recommends the companies to be more attention in the authentic leadership and organizational commitment and strengthening the organizational citizenship behavior.
\end{abstract}

Keywords: Authentic leadership, Organizational Citizenship Behavior, Organizational Commitment

Introduction

Authentic leadership represents one of modern expectations in leadership, and is established on the moral side of the leader behavior and is established on the trust between with his followers, which in turn, enhance creativity and innovation in the organizations (Sosik \& Jung, 2018). Therefore, a number of foreign researchers addressed it through studies and researches which connected their relations with different behavioral variables. At the same context, the behavioral studies confirmed the organizational citizenship behavior as part of volunteer behavior which promote the leader exchangeable relationship with his followers, and in turn, improve the 
organizational health of the establishments and confirm their distinguish in their organizational culture supporting their organizational success (Ahmad \& Zafar, 2018).

As for the organizational commitment, many researchers addressed them in their studies in order to clarify its role in enhancing the individual performance and the organizational productivity through its three types: Affective, continuance and normative. With the existence of a knowledge gap between what is researched in it of authentic leadership and its impact on the organizational citizenship behavior and the organizational commitment and between what should be made of more research efforts in this text (Joo \& Jo, 2017; Khan \& Rashid, 2012).

Thus, the purpose of this study is to measure the impact of authentic leadership in organizational citizenship behavior and employee's organizational commitment in the Jordanian companies.

\section{The Significant of the Study}

The importance of the study highlights the importance of the Authentic leadership in enhancing the positive behaviors and motivate them for the employees in the organizations in general and for the companies in particular, through providing supportive organizational environment for the organizational citizenship behavior which enhance the organizational commitment behavior for the employees in a framework to raise their productivity levels and leads to high levels of individual performance which enhance the organizational performance. Never the less, given the importance of the leadership subject and its position in the managerial operations in the Islamic Managerial Literature and the role which the leader play and lead it. The leader described as the heart to the body when mentioned that the heart surpasses the rest of the organs completely and perfectly, it is perfection by itself through its creation and formation of its parts. Also, in regard of what it is specialized in functions and works shared by other organs. As for the importance of honesty in leadership, the eighth characteristic came to ensure that the leader must love the truth and its people and hate lying and its people (Joo \& Jo, 2017).

Furthermore, and in view of the nature of the tasks given on the leader shoulder and the relationships with his subordinates. Current study manifests its importance by being analytical study in two parts, the first: shows the availability level of the authentic leadership in the companies researched, and the second: shows the level of organizational citizenship behavior and behavior ale commitment in the companies researched. In addition to that, the importance of the study guarantees providing leaders and companies managers with feedback about their leadership behavior and organizational citizenship behavior and organizational commitment for the employees, which form a new motive for the researchers to do similar studies on other communities other than companies sector.

\section{Previous Studies}

Many researchers and learners were interested in the subject of leadership and its theories and the leaders' characteristics and behaviors, and the organizational citizenship behavior subject, which helped in the emergence of field studies which researched in these subjects, and of these studies the following:

Al Sahi et al., (2016) study test the authentic leadership and its relations in the work connection and the organizational citizenship behavior for the employee from different countries in an Emirates oil company. The test was done by entering mediator variable which was the psychological empower, the results revealed that whenever the employees related and the 
organizational citizenship behavior enhanced the psychological increased which in turn strengthen the relations between them.

Peus, et al., (2012) study aimed to experimental test for the authentic leadership priorities represented in the self-knowledge and the internal consistency which is built on trust and its relations with the work satisfaction and the organizational commitment and the team efforts in the research organizations in Germany. The Result reached to the existence of a relation amongst the authentic leadership and the work satisfaction and the organizational commitment. It's recommended to perform more studies about the authentic leadership in the organizations. Leroy, et al., (2012) test the relation between the authentic leadership on the work group level and the integrity of the behavior on the individual level and between the emotional commitment for the followers and the performance. The study was performed on 49 work teams working in the services industry in America. The study found out the existence of a strong relation between the authentic leadership and the individual behavior integrity which the emotional commitment mediates it and leads to enhancing the performance of the work role. The current study benefited from the authentic leadership scale.

Khan and Rashid (2012), test the effect of the organizational commitment as a variable in the organizational culture on the organizational citizenship behavior and the organizational justice for the Academics in the Malaysian special higher education. The explorative study results revealed the existence of strong effect for the organizational commitment in the organizational citizenship behavior and recommended of performing more studies, which encourage on the adoption of the organizational citizenship behavior between academics in the universities.

Zhang, et al., (2012) study promoting the theory of the authentic leadership in the Chinese philosophy. The study was performed on eight Chinese organizations as a study case to check the western model in the authentic leadership and used interviews and notes as a data collective tools. The study achieved the western theory development to a theory serves the Chinese context in the practices and suggested a new model for it concentrating on two levers which are the related reliability and the self-reliability in harmony with the Confucianism philosophy.

Ali, et al., (2010) study testing the effect of organizational justice in the organizational citizenship behavior in the Pakistani Bank. The study sample consisted from 280 employees working in the Pakistani banks field, and reached to the existence of a positive relation between variables and the existence of positive effect for the procedural justice in the organizational citizenship behavior more than from the effect of the distributional justice in the organizational citizenship behavior.

Ceri-Booms, (2010) study, exploring the mediator role for the confidence in the leadership in the Authentic and reciprocal leadership forms through experimental study performed on the Turkish companies which are committed to the companies' governance, the companies consisted from 232 researches. As a result, both types of leadership (the Authentic and the reciprocal) have positive relation with trust in the leader, although it is more in favor of the Authentic leadership, which leads to the organizational assurance in the follower's behaviors such as their feelings as part of the company and part of its values, and are proud of their membership to those companies, and recommended of more studies in this particular.

Alomari,(2010) The research purpose is to identify the characteristics of the leader inherited and acquired from the perspective of al-Farabi and compare it with the most prominent theories and schools of intellectual contemporary in the leadership. The research contributes in providing 
useful information and knowledge in leadership field as a learning studies in the universities and training centers and institutions to develop leaders in different field such as training development and rehabilitation. The research purpose, importance, hypothesis, and problem. illustrate the task of research to build upon inference and measurement that lead to a group of conclusions and recommendations in the leadership knowledge field.

\section{Theoretical Framework and Related Hypotheses}

The independent variable in this study is the authentic leadership and the follower variable is the organizational citizenship behavior and the organizational commitment as shown in the following figure (1) hypothesis study form:

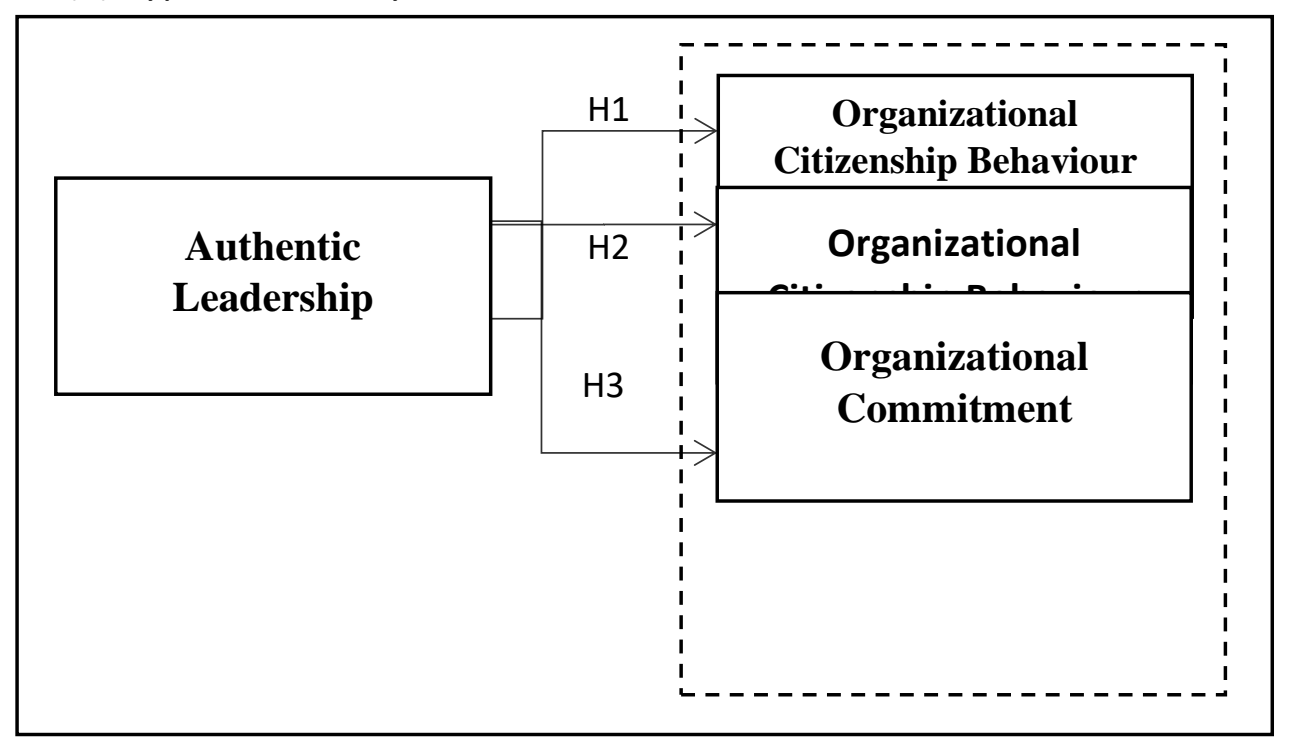

Figure 1: Research framework and related hypotheses

\section{Authentic Leadership}

Stephen, R, and Timothy,J (2017) define authentic leadership as it focuses on the ethics features built on trust disclosed by leaders towards subordinates, and that the authentic leader knows who himself, knows what his believes are, believes in his work with values in explicit open manner, helps the authentic leader in building trust joining subordinates in the information, encourages in open communicate, and possessing good standards Islam Nofal \& Yusof,( 2016). Authentic Leadership depends on two solid bases which are:

A. Ethics: The topic of ethics and its connections with leadership had little interest from the researchers, for reasons such as, the interest in the ethics system in management in general is growing and escalating in it pace due to its importance in the success of Authentic leadership and its distinction in management, and that the practices of the ethical leadership became looking for high ethical standards for its distinction from others. Transformational Leadership is described by its use of power through ethical priority appearances in changing the behavior and directions of the followers towards creativity and innovation through its four dimensions as follows:

1- The Ideal Effect: when the leader shares subordinates with his vision, then plant pride and build relations with them on trust and mutual respect. 
2- The inspiration motive: through bringing forth to high expectations and the use of simples, and concentrate on the prosperous efforts, and expressing the important issues in a simplified way.

3- The mental arouse: through encouraging intellectuality and rationality and solving organizational problems.

4- The concern for individuals: The transformed leader cares for his individuals and treats each one with the suitable treatment individually, through advice and training them.

The successful Charismatic leader uses the power of ethical effect on followers, also through leadership practices; does not distinguish him-self in salaries and big rewards in exchange to crushing their rights and merits. From here emerged new direction in leadership named The Social Charismatic Leadership which focuses on the values which the leader holds, and those subordinates hold in an agreeable direction leads to the social behavior desired in the establishment.

B. Trust: It is a positive expectation in thinking and action and decisions and built on two elements which are: The positive expectation which built on the knowledge and the desire in enduring the risk, which is built gradually and cumulatively. Seizing the established opportunities for the desire to take calculated risk. As for the dimensions of the trust it is five dimensions: stability, consistency, merit, loyalty, and openness. Their types are three: Trust built on deterrence, trust built on knowledge, and trust its basis is verification. Trust has solid relation with leadership; it establishes the supportive relation for corporation and participation in solving organizational problems supporting the organizational performance distinction.

This factor pointed to four dimensions for the authentic leadership which are: The self-awareness and in it stands out the ability to receive the feedback with understanding and awareness and does not affect the criticism operations around his weak points, and the strong points possess does not make arrogant and transparency in the relationships with others, has the readiness to admit being mistaken and derive from it. Ethics which relays to its system in decision making. Finally, the balanced treatment for firmly established opinions, which does not affect the palpate opinions which disagree with (Walumbwa, Avolio, Gardner, Wernsing, \& Peterson, 2008).

Leadership built on solid foundation of trust and good manners where the authentic leader knows him-self, his believes in the knowledge of values, and works on achieving those values and beliefs honestly and in public. It was measured through the received phrases in the questionnaire (1-16).

Hypothesis (H1): There is no impact found in the Authentic leadership in the organizational citizenship behavior and the organizational commitment for the employees in the Jordanian companies at the level of indication ( $a=0.05)$

\section{Organizational Citizenship Behavior}

The organizational citizenship behavior is the optional voluntary behavior, it is not part of the official work requirements, but goes beyond the expectations from the required performance, and appears in multiple behaviors such as helping others, and volunteering in extra work, and avoiding unnecessary conflict in the organization, and respect the legislations spirit and rules in the work (Shin, Kim, Choi, Kim, \& Oh, 2017). As a result, seven types pointed of organizational citizenship behavior which are: Help behavior, Sportsmanship spirit, Organizational loyalty, 
Organizational compliance, Individual initiative, Virtue behavior, and self-development (Holtom \& Sekiguchi, 2018).

It is an optional behavior not part of official work requirements, but encourage achieving its functions effectively and be beyond motivated expectations as if employees help others, and perform the voluntary works on his free will, and avoid the unnecessary conflicts in the work, and it has been measured through the phrases mentioned in the questionnaire (17-37).

Hypothesis (H2): There is no impact found for the Authentic leadership in the organizational citizenship behavior for the employees in the Jordanian companies at the level of indication (a=0.05).

\section{Organizational Commitment}

A functional direction expresses an agreeable felt condition between company objectives and the employee desires in remaining in the company membership (Nofal \& Yusof, 2016). Robbins confirms the existence of three types of organizational commitment which are:

- Affective Commitment means the employee connection emotionally in the organization and belief in its values.

o Continuance Commitment it is a commitment built the employee realization for the economic value which gets in comparison with the one he might lose it.

o Normative Commitment it is a commitment built on ethical and moral reasons.

It is a job direction expresses agreeable conscious condition between the company goals and the employee desires to remain as a company member, and is divided into three dimensions: emotional continuing and standard commitment. It was measured through the phrases mentioned in the questionnaire as follows: emotional (38-46), continuing (47-54), Normative (55-61).

Hypothesis (H3): There is no impact found for the Authentic leadership in the organizational commitment behavior in the Jordanian companies at the level of indication $(a=0.05)$.

\section{Research Method}

The study used the descriptive analytical research procedure being suitable to perform this research, whereas according to it can describe the study community and its variable, and analyze these variables in an equable scientific form. The community study consisted from Jordanian companies registered in the Financial Papers Noun-The Center represented by Managers, Assistants, and divisions' heads and department's heads. A simple random sample was taken consisted of 6 companies working in various sectors: two in the insurance sector, the Middle East insurance co., and Arab Eagle insurance co., and two in the industrial sector, Dar AIDawaa and Al-Intaj, and two in the financial sector- banks, the Jordan Islamic Bank and Jordan Kuwait Bank. The inspection unit is each individual belongs to any of the managerial jobs in the study community and includes: - (Managers, Assistants, divisions heads, and departments heads) in the Jordanian companies.

Sample size: The questionnaires were distributed to six companies, (36) questionnaires in total, after its retrieval it turned out that only (31) questionnaires were good for analysis which was filled by employees in the researched companies, and after analysis it turned out they work in four managerial levels: Managers (3), Assistants (7), divisions' heads (16), and departments' heads (29). 


\section{The Study Tools and the Sources of Data Collection}

The initial data were approved to collect the study data to provide the necessary data of the study sample, the researcher developed a questionnaire tool consisted of two parts:

1- First part: includes general information which includes characteristics of the sample individuals like: Social type, age, academic qualification, and the work period at the company, and the work position.

2- Second part: includes the following:

a. Indicators to measure the Authentic leadership which could be from the idioms (1-16) collectively, and depending on scale of Authentic leadership Self-Assessment Questionnaire (Anderson, 2016).

b. Indicators to measure the organizational citizenship behavior which could be from the idioms (17-37) depending on scale (Fox \& Spector, 2008).

c. Indicators to measure the organizational commitment which could be from the idioms (38-61) and that as following: emotional (38-46), continuing (47-54), standard (55-61) depending on the scale (Allen \& Meyer, 1990).

3- Other Sources: represented in books, seminars, and previous studies.

\section{The Validity and Stability of the Study tool}

Meant by the credibility of the tool (questionnaire), the degree of the tool capability to measure the variables which were designed to measure it, on this basis the tool was displayed to group of specialized master's in business management, management, and in number of universities like Amman Arab University, Jordan University, Al-Isra University, and Al-Zaytoonah University, and the translated and modified test image was revised, and modifications were entered based on the notes received from the judged masters.

As to the tools stability, it means how to get the same results if the study was repeated in similar conditions and with the same tools used. Cronbach's alpha scale was used to pin point the internal consistency for each section, and these tools counted good and suitable if the Cronbach alpha scale exceeds $60 \%$, therefore it is acceptable. When this test was implemented it was found that alpha value for all tool variables equals $94 \%$, and that alpha value for the variable of Authentic leadership equals $91 \%$, and alpha value for the variable of organizational citizenship behavior equals $90 \%$, and alpha value for the variable of organizational commitment equals $82 \%$, which are acceptable percentages because they are higher than the percentage familiar with.

\section{The Statistical Treatment}

The Statistical Package (SPSS) was adopted to analyze the study data, by using the following statistical methods:

1- Description Statistic Measures, to describe the characteristic of the study sample by percentage and answering the study questions and measurement phrases through mathematical averages and standard diversions.

2- The analysis of Linear Regression to test the validity of the study models and the effect of independent variables and dimensions on the follower variable.

\section{Data Analysis and Findings}

Descriptive Statics 
INTERNATIONAL JOURNAL OF ACADEMIC RESEARCH IN BUSINESS AND SOCIAL SCIENCES

Vol. 9, No. 11, November, 2019, E-ISSN: 2222-6990 ㄷ 2019 HRMARS

The Sample Properties Results

To answer the study question and test its theories, the statistical package (SPSS) was used to analyze the data which were collected; the following is a summary of the analysis results:

a. The sample properties in terms of social type:

Table (1): The Social Type

\begin{tabular}{|ll|c|c|c|c|}
\hline & Frequency & Percent & $\begin{array}{c}\text { Valid } \\
\text { Percent }\end{array}$ & $\begin{array}{c}\text { Cumulative } \\
\text { Percent }\end{array}$ \\
\hline Valid & 1 & 20 & 64.5 & 64.5 & 64.5 \\
& 2 & 11 & 35.5 & 35.5 & 100.0 \\
Total & 31 & 100.0 & 100.0 & \\
\hline
\end{tabular}

Table (1) shows the social type results for the sample where it displays the male percentage is $64.5 \%$ vs. the female percentage $35.5 \%$, and that indicates to a rise in the male percentage to the female. Which can be explained through the male community as it was mentioned in (Insights, 2018)study for the cultures amongst communities.

b. The sample properties in terms of age:

Table (2): Age

\begin{tabular}{|cc|c|c|c|c|}
\hline & Frequency & Percent & $\begin{array}{c}\text { Valid } \\
\text { Percent }\end{array}$ & $\begin{array}{c}\text { Cumulative } \\
\text { Percent }\end{array}$ \\
\hline Valid & 1 & 9 & 29.0 & 29.0 & 29.0 \\
& 2 & 15 & 48.4 & 48.4 & 77.4 \\
& 3 & 6 & 19.4 & 19.4 & 96.8 \\
& 4 & 1 & 3.2 & 3.2 & 100.0 \\
Total & 31 & 100.0 & 100.0 & \\
\hline
\end{tabular}

Table (2) shows the ages of the study sample where it displays that $29 \%$ of the age category $20-$ less than 29 , and that $48.4 \%$ of the age category 29 - less than 39 , and in conclusion, that indicates to the youth category capable and desired in the work in the companies field study community. Those percentages of who are above the age $39-59$ do not form more that $23.6 \%$ of the sample. While the sample was empty of who were their ages above 60 years which is the retirement age.

c. The sample properties in terms of academic qualifications:

Table (3): Academic Qualifications

\begin{tabular}{|cc|c|c|c|c|}
\hline & & Frequency & Percent & Valid Percent & $\begin{array}{c}\text { Cumulative } \\
\text { Percent }\end{array}$ \\
\hline Valid & 1 & 1 & 3.2 & 3.2 & 3.23 \\
& 3 & 20 & 64.5 & 64.5 & 67.7 \\
& 4 & 6 & 19.4 & 19.4 & 87.1 \\
& 5 & 4 & 12.9 & 12.9 & 100.0 \\
Total & & 31 & 100.0 & 100.0 & \\
\hline
\end{tabular}


Table (3) shows the academic qualifications for the study sample where it displays the bigger percentage 64.5 the Bachelors and this indicates on the availability in the Jordanian community and fulfills its market needs the study community.

d. The sample properties in terms the work period in the company:

Table (4): Work period in the company

\begin{tabular}{|cc|c|c|c|c|}
\hline & & Frequency & Percent & $\begin{array}{c}\text { Valid } \\
\text { Percent }\end{array}$ & $\begin{array}{c}\text { Cumulative } \\
\text { Percent }\end{array}$ \\
\hline Valid & 1 & 16 & 51.6 & 51.6 & 51.6 \\
& 2 & 7 & 22.6 & 22.6 & 74.2 \\
& 3 & 4 & .12 .9 & 12.9 & 87.1 \\
& 4 & 3 & 9.7 & 9.7 & 96.8 \\
& 5 & 1 & 3.2 & 3.2 & 100.0 \\
Total & 31 & 100.0 & 100.0 & \\
\hline
\end{tabular}

Table (4) Shows the work period in the company where it displays the bigger percentage $51.6 \%$ in favor the category from 1 - less than 5 years. Followed by second category with the percentage of $22.6 \%$ who are their service between 5 - less than 10 years. The rest of percentages are modest for the long years in service. This indicates on the employees circle in those companies.

4.1.1. The sample properties in terms of the functional position Table (5): The Functional Position

\begin{tabular}{|lc|c|c|c|c|}
\hline & & Frequency & Percent & $\begin{array}{c}\text { Valid } \\
\text { Percent }\end{array}$ & $\begin{array}{c}\text { Cumulative } \\
\text { Percent }\end{array}$ \\
\hline Valid & 1 & 3 & 9.7 & 9.7 & 9.7 \\
& 2 & 2 & 6.5 & 6.5 & 16.1 \\
& 3 & 6 & 19.4 & 19.4 & 35.5 \\
& 4 & 12 & 38.7 & 38.7 & 74.2 \\
& 5 & 8 & 25.8 & 25.8 & 100.0 \\
Total & & 31 & 100.0 & 100.0 & \\
\hline
\end{tabular}

Table (5) shows the functional position for the employees in the companies the study community, where it displays the percentage convergence $9.7 \%$ to $6.5 \%$ between the manager position and the assistant manager, whereas the bigger percentage $38.7 \%$ came in favor of the department head which is in coherence with the Organizational pyramid in the study community.

4.2. Measurement model

The Likert Scale was used in building the questionnaire to express the following weights ( 1 does not agree completely, 2 do not agree, 3 neutral, 4 agree, 5 agree completely). To reach to three levels we measure the importance of the study variables, therefore the following equation was used:

$1-5 / 3=1.33$

$1-2.33 \quad$ Low

2.34-3.67 Average

3.68-5 High

4.3. Structural model 
4.3.1. The Authentic leadership levels

Table (6) explains the mathematical averages and the standard deviations and phrases level which according to it the authentic leadership was measured in the researched companies:

Table (6): The Mathematical Averages and Standard Deviations and the Authentic leadership level

\begin{tabular}{|c|c|c|c|c|}
\hline & Phrase & $\begin{array}{l}\text { Mathemati } \\
\text { cal Average }\end{array}$ & $\begin{array}{l}\text { Standard } \\
\text { Deviation }\end{array}$ & Level \\
\hline & $\begin{array}{l}\text { Authentic leadership: I see my manager as a } \\
\text { leader }\end{array}$ & & & \\
\hline 1. & $\begin{array}{l}\text { He can insert the greatest three points of his } \\
\text { weak points }\end{array}$ & 2.71 & 1.131 & $\begin{array}{l}\text { Avera } \\
\text { ge }\end{array}$ \\
\hline 2. & $\begin{array}{l}\text { He can insert the greatest three points of his } \\
\text { strong points }\end{array}$ & 3.97 & 0.875 & High \\
\hline 3. & $\begin{array}{l}\text { Searches the reality about the feedback what I } \\
\text { am as a person }\end{array}$ & 4.03 & 1.016 & High \\
\hline 4. & Accept emotion around himself & 3.29 & 1.131 & $\begin{array}{l}\text { Avera } \\
\text { ge }\end{array}$ \\
\hline 5. & My managers" actions reflects the essence value & 4.06 & 0.998 & High \\
\hline 6. & Does not allow the group pressure to control him & 4.03 & 1.110 & High \\
\hline 7. & $\begin{array}{l}\text { Others know where the manager stands in the } \\
\text { controversial cases }\end{array}$ & 3.94 & 1.093 & High \\
\hline 8. & Morals directing to the work done & 3.94 & 1.031 & High \\
\hline 9. & $\begin{array}{l}\text { Searches for the others opinions before decision } \\
\text { making, }\end{array}$ & 3.90 & 0.944 & High \\
\hline 10. & $\begin{array}{l}\text { Listens closely to the opinions of those disagree } \\
\text { with his opinion }\end{array}$ & 3.65 & 0.950 & $\begin{array}{l}\text { Avera } \\
\text { ge }\end{array}$ \\
\hline 11. & $\begin{array}{l}\text { Does not confirm own point of view on account } \\
\text { to others points of view }\end{array}$ & 3.58 & 1.089 & $\begin{array}{l}\text { Avera } \\
\text { ge }\end{array}$ \\
\hline 12. & $\begin{array}{l}\text { Listens good to the opinions of others before } \\
\text { making a decision }\end{array}$ & 3.81 & 0.980 & High \\
\hline 13. & He honestly shares his feelings with others & 3.32 & 1.045 & $\begin{array}{l}\text { Avera } \\
\text { ge }\end{array}$ \\
\hline 14. & Let others know his true personality & 3.23 & 1.023 & $\begin{array}{l}\text { Avera } \\
\text { ge }\end{array}$ \\
\hline 15. & Rarely make 'a mistake' towards others & 2.97 & 1.303 & $\begin{array}{l}\text { Avera } \\
\text { ge }\end{array}$ \\
\hline \multirow[t]{2}{*}{16.} & Admit mistakes to others & 2.81 & 1.250 & $\begin{array}{l}\text { Avera } \\
\text { ge }\end{array}$ \\
\hline & The General Average & 3.58 & & $\begin{array}{l}\text { Avera } \\
\text { ge }\end{array}$ \\
\hline
\end{tabular}

Table (6) shows the properties and practices of the authentic leadership from the employees point of view, where it became clear that the general average is 3.58 which is an average level. 
The highest high standards indicate as mentioned in the six phrase that manager's actions reflect the essentialism values, and that supports the ethical orientation for the managers with a high average its measure 4.06 and it is the essence of the Authentic leadership. Whereas the lowest levels came and it is less than the general average for the first phrase which expresses the inclusion of the manager to the greatest tree points expressing weakness by mathematical average 2.71 followed by phrase 16 by the managers' confessing mistakes towards others by average 2.81 , which reflects a culture the community needs as a value not reducing the person organizational and humanitarian position when confessing weakness and repent from own mistake to the favor of the wisdom in behavior and manners.

\section{The levels of Organizational Citizenship Behavior}

Table (7) explains the results of the mathematical averages and standard deviations and the level of organizational citizenship behavior in the researched companies as follows:

Table (7): The mathematical averages and the standard deviations and the organizational citizenship behavior

\begin{tabular}{|l|l|c|l|l|}
\hline & Phrases & $\begin{array}{l}\text { Mathemati } \\
\text { cal Average }\end{array}$ & $\begin{array}{l}\text { Standar } \\
\text { d } \\
\text { Deviati } \\
\text { on }\end{array}$ & Level \\
\hline 17 & $\begin{array}{l}\text { I help the company employees to achieve their } \\
\text { tasks }\end{array}$ & 4.19 & 0.910 & High \\
\hline 18 & $\begin{array}{l}\text { I help the new company employees by solving } \\
\text { the work problems face with. }\end{array}$ & 4.06 & 0.854 & High \\
\hline 19 & $\begin{array}{l}\text { I share the new employees to get more } \\
\text { knowledge about the work }\end{array}$ & 4.16 & 0.688 & High \\
\hline 20 & $\begin{array}{l}\text { I take care of the volunteer ale behaviors which } \\
\text { exceeds the work roles demand }\end{array}$ & 3.77 & 0.956 & High \\
\hline 21 & $\begin{array}{l}\text { I always make sure on increasing the company } \\
\text { profitability }\end{array}$ & 4.32 & 0.791 & High \\
\hline 22 & $\begin{array}{l}\text { I make sure to minimize as much possible from } \\
\text { the break time on the work account }\end{array}$ & 3.97 & 0.795 & High \\
\hline 23 & I respect the work procedures in the company & 4.29 & 0.693 & High \\
\hline 24 & I respect the company's work rules & 4.39 & 0.761 & High \\
\hline 25 & I respect the company's work laws & 4.39 & 0.715 & High \\
\hline 26 & I endure the work hardship without boring & 4.00 & 1.065 & High \\
\hline 27 & $\begin{array}{l}\text { I endure the critical work conditions with } \\
\text { tolerance }\end{array}$ & 4.26 & 0.773 & High \\
\hline 28 & $\begin{array}{l}\text { I respect my work responsibility in the company } \\
\text { as a member in it }\end{array}$ & 4.32 & 0.653 & High \\
\hline 29 & $\begin{array}{l}\text { I display the company's good image in its } \\
\text { external habitat }\end{array}$ & 4.16 & 0.688 & High \\
\hline
\end{tabular}


INTERNATIONAL JOURNAL OF ACADEMIC RESEARCH IN BUSINESS AND SOCIAL SCIENCES Vol. 9, No. 11, November, 2019, E-ISSN: 2222-6990 @ 2019 HRMARS

\begin{tabular}{|l|l|c|c|l|}
\hline 30 & $\begin{array}{l}\text { I defend the company's reputation towards } \\
\text { external threats even though on my personal } \\
\text { benefit }\end{array}$ & 3.39 & 1.054 & $\begin{array}{l}\text { Averag } \\
\mathrm{e}\end{array}$ \\
\hline 31 & $\begin{array}{l}\text { I use my personal car to reach places my work } \\
\text { needs with no charge }\end{array}$ & 3.45 & 1.121 & $\begin{array}{l}\text { Averag } \\
\text { e }\end{array}$ \\
\hline 32 & $\begin{array}{l}\text { I suggest the continuous improvements to } \\
\text { perform the work with good quality }\end{array}$ & 4.06 & 0.680 & High \\
\hline 33 & $\begin{array}{l}\text { I suggest the continuous improvements in the } \\
\text { work environment }\end{array}$ & 4.23 & 0.762 & High \\
\hline 34 & $\begin{array}{l}\text { I make sure coming to work early before the } \\
\text { official working hours with no charge }\end{array}$ & 3.71 & 1.006 & High \\
\hline 35 & $\begin{array}{l}\text { I make sure to stay up late at work after working } \\
\text { hours with no charge }\end{array}$ & 3.26 & 1.290 & $\begin{array}{l}\text { Averag } \\
\text { e }\end{array}$ \\
\hline 36 & $\begin{array}{l}\text { I do voluntary works at the job the official work } \\
\text { does not acquire it }\end{array}$ & 3.29 & 0.938 & $\begin{array}{l}\text { Averag } \\
\text { e }\end{array}$ \\
\hline 37 & $\begin{array}{l}\text { I bring home my work assignments to prepare } \\
\text { them for the next day }\end{array}$ & 3.16 & 1.128 & $\begin{array}{l}\text { Averag } \\
\text { e }\end{array}$ \\
\hline & The General Average & 3.94 & & High \\
\hline
\end{tabular}

Table (7) results illustrate the organizational citizenship behavior for the employees in the researched companies, where it shows the general average came in a high standard which is 3.94. the highest levels indicate a rise as shown in the two phrases 24 and 25 where the mathematical average for both of them reached 4.39 with two standard deviations 0.715 and 0.761 respectively, which indicates to the behavior of employee's respect for the laws and rules of the work in the researched companies which indicates the formality in it. That was followed by the phrase 21 which includes the employees' devotion on increasing the researched companies' profitability with a mathematical average 4.32 and standard deviation 0.791 . whereas the lowest mathematical average measures came for the last phrase with an average level with 3.16 and standard deviation 1.128, and that is lower than the general average, and point out to bringing work assignments home by the employees to prepare them for the next day, which is interpreted as the employees doing their work during official working hours in consideration to the nature of their functional duties and tasks.

\section{The Organizational Commitment Levels}

Table (8) illustrates the mathematical averages analysis and the standard deviations and the level for the phrases which measured the organizational commitment in the researched companies as follows: 
Table (8): The Mathematical Averages and the Standard Deviations and the level for the Organizational Commitment

\begin{tabular}{|c|c|c|c|c|}
\hline & Phrases & $\begin{array}{l}\text { Mathemati } \\
\text { cal Average }\end{array}$ & $\begin{array}{l}\text { Standard } \\
\text { Deviatio } \\
\mathbf{n}\end{array}$ & Level \\
\hline \multicolumn{5}{|c|}{ Organizational commitment affective (emotional) } \\
\hline 38 & $\begin{array}{l}\text { I'll be happy to spend the rest of my career life } \\
\text { in the company }\end{array}$ & 3.29 & 1.106 & $\begin{array}{l}\text { Averag } \\
\mathrm{e}\end{array}$ \\
\hline 39 & $\begin{array}{l}\text { I enjoy discussing my company's' conditions } \\
\text { with other persons outside it }\end{array}$ & 3.10 & 1.018 & $\begin{array}{l}\text { Averag } \\
\mathrm{e}\end{array}$ \\
\hline 40 & $\begin{array}{l}\text { I feel that my company's problems are my } \\
\text { problems }\end{array}$ & 3.35 & 0.985 & $\begin{array}{l}\text { Averag } \\
\mathrm{e}\end{array}$ \\
\hline 41 & $\begin{array}{l}\text { I believe that I can communicate with other } \\
\text { companies easily as is the case in my company }\end{array}$ & 3.35 & 1.023 & $\begin{array}{l}\text { Averag } \\
\mathrm{e}\end{array}$ \\
\hline 42 & $\begin{array}{l}\text { I feel that I am 'part of my family' in my } \\
\text { company }\end{array}$ & 4.23 & 1.044 & High \\
\hline 43 & I feel with an emotional bonding in my company & 4.10 & 1.071 & High \\
\hline 44 & $\begin{array}{l}\text { My company has a lot of personal meaning to } \\
\text { me }\end{array}$ & 3.71 & 1.110 & High \\
\hline 45 & $\begin{array}{l}\text { I don't feel with strong affiliation to my } \\
\text { company }\end{array}$ & 4.03 & 0.973 & High \\
\hline 46 & Mathematical Average & 3.64 & & $\begin{array}{l}\text { Averag } \\
\mathrm{e}\end{array}$ \\
\hline \multicolumn{5}{|c|}{ The continuous Commitment } \\
\hline 47 & $\begin{array}{l}\text { I am not afraid of what would happen if I left my } \\
\text { work without getting another job }\end{array}$ & 3.26 & 1.064 & $\begin{array}{l}\text { Averag } \\
\mathrm{e}\end{array}$ \\
\hline 48 & $\begin{array}{l}\text { It will be very hard to leave my company even if } \\
\text { I desired it. }\end{array}$ & 3.26 & 0.996 & $\begin{array}{l}\text { Averag } \\
\mathrm{e}\end{array}$ \\
\hline 49 & $\begin{array}{l}\text { I will face a lot of obstacles in my life if I left my } \\
\text { company }\end{array}$ & 3.48 & 1.057 & $\begin{array}{l}\text { Averag } \\
\mathrm{e}\end{array}$ \\
\hline 50 & $\begin{array}{l}\text { It will not cost me much if I left working in my } \\
\text { company }\end{array}$ & 2.42 & 1.165 & $\begin{array}{l}\text { Averag } \\
\mathrm{e}\end{array}$ \\
\hline 51 & $\begin{array}{l}\text { Staying in my company is a necessary matter to } \\
\text { fulfill my desire till now }\end{array}$ & 2.90 & 0.962 & $\begin{array}{l}\text { Averag } \\
\text { e }\end{array}$ \\
\hline 52 & $\begin{array}{l}\text { I feel that I have very few options if I left my } \\
\text { company }\end{array}$ & 3.52 & 1.264 & $\begin{array}{l}\text { Averag } \\
\mathrm{e}\end{array}$ \\
\hline 53 & $\begin{array}{l}\text { One of the dangerous consequences of leaving } \\
\text { work in my country is the scarcity of available } \\
\text { alternatives }\end{array}$ & 2.74 & 1.336 & $\begin{array}{l}\text { Averag } \\
\text { e }\end{array}$ \\
\hline 54 & $\begin{array}{l}\text { One of the main reasons to continue working in } \\
\text { my company is that leaving it acquire a big } \\
\text { personal sacrifice of few public interest }\end{array}$ & 2.58 & 1.023 & $\begin{array}{l}\text { Averag } \\
\text { e }\end{array}$ \\
\hline
\end{tabular}


INTERNATIONAL JOURNAL OF ACADEMIC RESEARCH IN BUSINESS AND SOCIAL SCIENCES

Vol. 9, No. 11, November, 2019, E-ISSN: 2222-6990 @ 2019 HRMARS

\begin{tabular}{|c|c|c|c|c|}
\hline & $\begin{array}{l}\text { collected in it which another company cannot } \\
\text { compensate me }\end{array}$ & & & \\
\hline & Mathematical Average & 3.02 & & $\begin{array}{l}\text { Averag } \\
\mathrm{e}\end{array}$ \\
\hline \multicolumn{5}{|c|}{ The Normative Commitment } \\
\hline 55 & $\begin{array}{l}\text { These days I think that the individuals are } \\
\text { moving from one company to another most of } \\
\text { the time }\end{array}$ & 3.58 & 0.958 & High \\
\hline 56 & $\begin{array}{l}\text { Jumping from one company to another does } \\
\text { not seem in all conditions a none ethical act }\end{array}$ & 3.77 & 0.884 & High \\
\hline 57 & $\begin{array}{l}\text { One of the main reasons to continue work in my } \\
\text { company is my belief that loyalty to it is an } \\
\text { ethical commitment courtesy to stay }\end{array}$ & 3.35 & 1.199 & $\begin{array}{l}\text { Averag } \\
\text { e }\end{array}$ \\
\hline 58 & $\begin{array}{l}\text { If I got a better offer to work in another } \\
\text { company I don't feel its right to leave working } \\
\text { in my company }\end{array}$ & 2.65 & 1.330 & $\begin{array}{l}\text { Averag } \\
\text { e }\end{array}$ \\
\hline 59 & $\begin{array}{l}\text { I learned the belief of the loyalty value to stay } \\
\text { for one company }\end{array}$ & 3.23 & 1.146 & $\begin{array}{l}\text { Averag } \\
\text { e }\end{array}$ \\
\hline 60 & $\begin{array}{l}\text { Work was better those days where individuals } \\
\text { stay in the company during their entire career }\end{array}$ & 3.13 & 1.024 & $\begin{array}{l}\text { Averag } \\
\text { e }\end{array}$ \\
\hline \multirow[t]{3}{*}{61} & $\begin{array}{l}\text { I don't believe that "the company as a man" or } \\
\text { "the company as a woman" sane }\end{array}$ & 3.39 & 1.086 & $\begin{array}{l}\text { Averag } \\
\text { e }\end{array}$ \\
\hline & The mathematical average & 3.3 & & $\begin{array}{l}\text { Averag } \\
\text { e }\end{array}$ \\
\hline & The General Average & 3.32 & & $\begin{array}{l}\text { Averag } \\
\text { e }\end{array}$ \\
\hline
\end{tabular}

Table (8) shows the organizational commitment levels in the researched companies with general level average 3.36 and through types of the organizational commitment, the higher level came for the emotional commitment, where the mathematical average for it reached 3.64 which are also higher than the general average. Followed by the normative commitment which the mathematical average for it reached 3.3, which is also less than the general average. In the last position came the continuous commitment level with a mathematical average 3.02 which is less than the general mathematical average. Through observing the results of each type of the organizational commitment types, the results came as follows:

a. The highest levels of affective (emotional) commitment and at a high level for the phrase (42) whereas the mathematical average reached 4.23 and standard deviation 1.04 and which it expressed the feelings of the employees as part of their families in the company. Whereas the lowest levels came for the phrase (40) and which it showed average levels 3.10 and standard deviation 1.018 in which the researched expressed their dissatisfaction in discussing the companies' conditions with outside people, and it is less than the general average for this type of emotional commitment and less too from the general average for the organizational 
commitment in general, and it indicates the secrecy and undesired disclosure of their company's' conditions.

b. As the levels of the Normative commitment came in second place, where the general average for it reached 3.41 in an average level but higher than the general mathematical average for the organizational commitment. In it the phrase (59) came to express the employees' belief that should be always loyal to the company a high mathematical average 4.16 and standard deviation 1.330, and it is an average level and less than the general average for the standard organizational commitment, and in which the employees working in it expressed their feelings that it is not right to leave their work in their companies if received better offer to work in other companies.

c.It came in the last place in terms of the continuous commitment level, and in it appears that the highest level represented by the phrase (52) and which includes the employees feel that he has very few options if he left his company where the mathematical average for the phrase is 3.52, and it is higher from the mathematical average of the continuous commitment 3.02, and higher than the general mathematical average in general, where the general average reached 3.36. While the phrase (50) was the less with a mathematical average 2.42 and standard deviation 1.156 and it indicates that leaving the current work in the company will not cost the employees much and it is less level from all the organizational commitment levels, this indicates that the confiscations in the companies are not tempting and motivational for the employees to stay in.

\section{Hypotheses Testing}

1- Testing the first hypothesis which was built on it and its context 'there is no impact for the Authentic leadership in the organizational citizenship behavior and the organizational commitment in the Jordanian companies at the significance level $a=0.05$, Analysis of variance regression was made and the analysis results were displayed as follows:

Table (9): Summary of the Regression Analysis for the authentic leadership in the organizational citizenship behavior and the organizational commitment

\begin{tabular}{|c|c|c|c|c|}
\hline Model & $\mathrm{R}$ & $\mathrm{R}$ Square & $\begin{array}{c}\text { Adjusted } \\
\text { R Square }\end{array}$ & $\begin{array}{c}\text { Std. Error of } \\
\text { The Estimate }\end{array}$ \\
\hline 1 & $0.764^{\mathrm{a}}$ & 0.584 & 0.570 & 0.291 \\
\hline
\end{tabular}

a. Predictors: (Constant), AULEADER

Analysis of the Variance Regression for the authentic leadership in the organizational citizenship behavior and the organizational commitment

Table (10): ANOVA $^{b}$ for the authentic leadership in the organizational citizenship behavior and the organizational commitment

\begin{tabular}{|ll|c|c|c|c|c|}
\hline & Model & $\begin{array}{c}\text { Sum of } \\
\text { Squares }\end{array}$ & Df & Mean Square & $F$ & Sig. \\
\hline $1 \quad$ Regression & 3.442 & 1 & 3.442 & 40.695 & $0.000^{\mathrm{a}}$ \\
& Residual & 2.453 & 29 & 0.085 & & \\
\multicolumn{2}{|c|}{ Total } & 5.894 & 30 & & & \\
\hline
\end{tabular}

a. Predictors: (Constant), AULEADER

b. Dependent Variable: OCBOC

Results of the Regression Analysis for the authentic leadership in the organizational citizenship behavior and the organizational commitment 
INTERNATIONAL JOURNAL OF ACADEMIC RESEARCH IN BUSINESS AND SOCIAL SCIENCES

Vol. 9, No. 11, November, 2019, E-ISSN: 2222-6990 @ 2019 HRMARS

Table (11): Coefficients ${ }^{a}$ for the authentic leadership in the organizational citizenship behavior and the organizational commitment

\begin{tabular}{|c|c|c|c|c|c|c|}
\hline & \multirow[b]{2}{*}{ Model } & \multicolumn{2}{|c|}{$\begin{array}{l}\text { Un-standardized } \\
\text { Coefficients }\end{array}$} & $\begin{array}{c}\text { Standardized } \\
\text { Coefficients }\end{array}$ & \multirow[t]{2}{*}{$\mathrm{T}$} & \multirow[t]{2}{*}{ Sig. } \\
\hline & & B & $\begin{array}{l}\text { Std. } \\
\text { Error }\end{array}$ & Beta & & \\
\hline \multirow[t]{2}{*}{1} & (Constant) & 1.763 & 0.279 & & 6.308 & 0.000 \\
\hline & AULEADER & 0.490 & 0.077 & 0.764 & 6.379 & 0.000 \\
\hline
\end{tabular}

a. Dependent Variable: OCBOC

Tables $(9,10$, and 11$)$ illustrates summary of the simple regression analysis the Duo correlation coefficient between the Authentic leadership and the organizational citizenship behavior and the organizational commitment, which reached 0.764 strong correlation and positive, which means that an increase in the Authentic leadership practices increase the organizational citizenship behavior and the organizational commitment for the employees in the researched companies. After reviewing the value of $R^{2}$ which equals 0.58 it indicates the capability of the Authentic Leadership variable in predicting the organizational citizenship behavior and the organizational commitment for the employees.

As shown the connotation of this built value in the Variance Regression Table (10) through value of test $\mathrm{F}$ which shows that the capability of the Authentic leadership variable in predicting the organizational citizenship behavior and the organizational commitment statistically accepted when reached 40.69 which is a moral indication at the level 0.000 and it is less than 0.05 , therefore rejects the hypothesis of zero and accepts the alternative hypothesis which its context 'there is an impact of the Authentic leadership in the organizational citizenship and the organizational commitment for the employees in the Jordanian companies at a connotation level $a=0.05$ through the values of $a$ and $B$ which appeared in the Table (11) the regression analysis, it is possible to predict the organizational citizenship behavior and the organizational commitment through the prediction formula as follows: $Y=a+B 1 \times 1+e$

Organizational citizenship behavior and organizational commitment $=$

\section{$1.763+0.490 \times$ authentic leadership}

To explain the effect in an easier way, we look to the standard value between two variables and it is value of Beta in the Table (11) which is used to predict the standard values of the dependent variable through the standard values of the independent variable as follows:

The standard value for the organizational citizenship behavior and the organizational commitment $=1.763+0.490 \times$ authentic leadership. This means that to increase on unit of organizational citizenship behavior and organizational commitment by $=1.763+0.490 \times$ authentic leadership

Test second hypothesis which is built on it, and which its context ' there is no impact of Authentic leadership in the organizational citizenship behavior for the workers in the Jordanian companies at significance level $a=0.05$, the simple bi analysis of the variance regression was made and the analysis results were displayed as follows:

The next table is a simple regression analysis summary for the Authentic Leadership in the organizational citizenship behavior 
INTERNATIONAL JOURNAL OF ACADEMIC RESEARCH IN BUSINESS AND SOCIAL SCIENCES

Vol. 9, No. 11, November, 2019, E-ISSN: 2222-6990 @ 2019 HRMARS

Table (12): Model Summary

\begin{tabular}{|c|c|c|c|c|}
\hline Model & $\mathrm{R}$ & $\mathrm{R}$ Square & $\begin{array}{c}\text { Adjusted R } \\
\text { Square }\end{array}$ & $\begin{array}{c}\text { Std. Error of } \\
\text { the Estimate }\end{array}$ \\
\hline 1 & $0.708^{\mathrm{a}}$ & 0.502 & 0.485 & 0.368 \\
\hline
\end{tabular}

a . predictors (Constant), AULEADER

Analysis of the Variance regression for the Authentic Leadership in the organizational citizenship behavior

Table (13): ANOVA for the Authentic Leadership in the organizational citizenship behavior

\begin{tabular}{|c|c|c|c|c|c|}
\hline Model & $\begin{array}{c}\text { Sum of } \\
\text { Squares }\end{array}$ & $\mathrm{df}$ & Mean Square & $\mathrm{F}$ & Sig. \\
\hline 1 & 3.965 & 1 & 3.965 & 29.218 & .000 \\
& 3.936 & 29 & .136 & & \\
& 7.901 & 30 & & & \\
\hline
\end{tabular}

a. Predictors: (Constant), AULEADER

b. Dependent Variable: OCBEAVE

The next table is the results of the Regression Analysis for the Authentic Leadership in organizational citizenship behavior

Table (14): Coefficients ${ }^{a}$ for the Authentic Leadership in organizational citizenship behavior

\begin{tabular}{|c|c|c|c|c|c|}
\hline \multirow[b]{2}{*}{ Model } & \multicolumn{2}{|c|}{$\begin{array}{l}\text { Unstandardized } \\
\text { Coefficients }\end{array}$} & $\begin{array}{l}\text { Standardized } \\
\text { Coefficients }\end{array}$ & \multirow[t]{2}{*}{$\mathrm{T}$} & \multirow[t]{2}{*}{ Sig. } \\
\hline & B & Std. Error & Beta & & \\
\hline (Constant) & 2.065 & .354 & & 5.834 & .000 \\
\hline AULEADER & .526 & .097 & .708 & 5.405 & .000 \\
\hline
\end{tabular}

a.Dependent Variable: OCBEAVE

Tables (12, 13, and 14) illustrates summary of the analysis of simple regression the duo correlation coefficient between the Authentic leadership and the organizational citizenship behavior which was 0.708 a strong positive bond meaning that an increase in practices of the Authentic leadership increase the organizational citizenship behavior and the organizational commitment for the workers in the researched companies. After reviewing the value of R2 which is 0.502 it indicates the capability of the authentic leadership variable in predicting the organizational citizenship variable for the workers.

Also, the value indication built in the Variance Regression Table (13) showed through value of test $F$ which shows the capability of the Authentic leadership variable is acceptable statically which reached 29.218 which is a moral indicator on level 0.000 and is less than 0.05 , therefore, rejects the zero hypothesis and accepts the alternative hypothesis which its context ' there is an impact of Authentic leadership in the organizational citizenship behavior for the workers in the Jordanian companies at indicator level $\mathrm{a}=0.05$. 
Through values of a and B which appeared in the Table (14) the regression Analysis, it is possible to predict the organizational citizenship behavior through the prediction equation as the following form:

$\mathrm{Y}=\mathrm{a}+\mathrm{B} 1 \times 1+\mathrm{e}$

The organizational citizenship behavior $=2.065+.526 \times$ the Authentic leadership

To explain the effect in an easier image, the study looks at the standard value between two variables which is the value Beta in table (11) and in which it's used to predict the standard value for the dependent variable through the standard variables of the independent variable as the following:

The standard value for the organizational citizenship behavior $=0.708 \times$ the standard value of the Authentic leaderships. It means that an increase in the authentic leadership variable by one degree accompanies by an increase in the organizational citizenship behavior by the amount of $2.065+.526 \times$ the Authentic leadership

Test of the third hypothesis which its context: there is no effect for the authentic leadership in the organizational commitment for the workers in the Jordanian companies at indicator level a $=0.05$, an Analysis for the simple duo variance regression was done and the analysis results were displayed as the following:

A Summary of Simple Regression Analysis for the authentic leadership in the organizational commitment

Table (15): Model Summary
\begin{tabular}{|c|c|c|c|c|}
\hline Model & $\mathrm{R}$ & R Square & $\begin{array}{c}\text { Adjusted } \\
\text { R Square }\end{array}$ & $\begin{array}{c}\text { Std. Error of the } \\
\text { Estimate }\end{array}$ \\
\hline 1 & $0.627^{\mathrm{a}}$ & 0.393 & 0.372 & 0.383 \\
\hline
\end{tabular}

a. Prediction: (Constant), AULEADER

The Variance of Regression Analysis for the authentic Leadership in the organizational commitment

Table (16)ANOVA for the Authentic Leadership in the organizational commitment

\begin{tabular}{|ll|c|c|c|c|c|}
\hline \multicolumn{2}{|l|}{ Model } & $\begin{array}{c}\text { Sum of } \\
\text { Squares }\end{array}$ & $\mathrm{df}$ & Mean Square & $\mathrm{F}$ & Sig. \\
\hline $1 \quad$ Regression & 2.752 & 1 & 2.752 & 18.742 & $0.000^{\mathrm{a}}$ \\
\multicolumn{2}{|l|}{ Total } & 4.258 & 29 & 0.147 & & \\
\hline
\end{tabular}

a. Predictors: (Constant), AULEADER

b. Dependent Variable: OCOMITM

The results of the regression analysis for the authentic leadership in the organizational commitment 
INTERNATIONAL JOURNAL OF ACADEMIC RESEARCH IN BUSINESS AND SOCIAL SCIENCES

Vol. 9, No. 11, November, 2019, E-ISSN: 2222-6990 @ 2019 HRMARS

Table (17): Coefficients ${ }^{a}$ for the Authentic leadership in the organizational commitment

\begin{tabular}{|cc|c|c|c|c|c|}
\hline \multirow{2}{*}{ Model } & \multicolumn{2}{|c|}{$\begin{array}{c}\text { Unstandardized } \\
\text { Coefficients }\end{array}$} & $\begin{array}{c}\text { Standardized } \\
\text { Coefficients }\end{array}$ & & \\
\cline { 3 - 5 } & B & Std. Error & Beta & t & Sig. \\
\hline 1 & (Constant) & 1.425 & 0.368 & & 3.870 & 0.001 \\
& AULEADER & 0.438 & 0.101 & 0.627 & 4.329 & 0.000 \\
\hline
\end{tabular}

a. Dependent Variables: OCOMITM

Tables $(15,16$, and 17$)$ illustrates a summary of the analysis of simple regression the duo correlation coefficient between the Authentic leadership and the organizational commitment which reached 0.627 a positive connection in the meaning that an increase in the practices of the Authentic Leadership increases the organizational citizenship behavior for the workers in the researched companies. By reviewing the value of $R^{2}$ which is 0.393 , it indicates the capability of the authentic leadership variable in predicting the organizational citizenship behavior and the organizational commitment for the workers.

Also, the built value indicator explained in Table (15) through test value $F$ which shows that the capability of the Authentic leadership variable in predicting the organizational commitment is statistically acceptable where it reached 18.74 , and it is a moral indicator to level 0.000 which is less than 0.05 therefore, rejects the zero hypothesis and accepts the alternative hypothesis which its context "there is impact of Authentic leadership in the organizational commitment for the employees in the Jordanian companies at an indicator level $a=0.05$.

Through values of a and B which both appeared in the Table (16) the regression analysis, it can be predicted with the organizational commitment through the prediction equation on the following form:

$$
\mathrm{Y}=\mathrm{a}+\mathrm{B} 1 \times 1+\mathrm{e}
$$

The organizational commitment $=1.425+.438 \times$ Authentic leadership

To explain the effect in a much easier picture, we look to the standard value between the variables which are the value of Beta in the Table (14), and in which is used to predict the standard values for the dependent variable through the standard variables of the independent variable as the following:

The standard value for the organizational commitment $=1.425+.438 \times$ Authentic leadership. That means, an increase organizational commitment one degree will accompany it an increase in $=1.425+.438 \times$ Authentic leadership

\section{Results and Recommendations}

The results can be summarized which the study reached to the existence of high levels of the organizational citizenship behavior and medium of the authentic leadership and organizational commitment in the researched Jordanian companies. The existence of a positive effect indicates statistically to the Authentic leadership in the organizational citizenship behavior and the organizational commitment, this is consistent with study results (Peus et al., 2012) in Germany, so in variables of the Authentic leadership and its effect in the organizational commitment. The study of Al Sahi AL Zaabi et al. (2016) in Emirates, the result was the existence of a positive effect indicates statistically and in a strong degree between the authentic leadership and the organizational citizenship behavior in the Jordanian companies. This is relatively consistent with study Ceri-Booms (2010) in Turkey in the Authentic leadership variable and its effect in the trust. 
Finally, the existence of a positive effect indicates statistically and in medium degree between the authentic leadership and the organizational commitment in the Jordanian companies. This is relatively consistent with studies of Leroy et al. (2012) in America and especially in the emotional commitment, which is relatively differs from study (Khan \& Rashid, 2012) in Malaysia.

\section{Conclusion}

Based on the results which the study reached, the following recommendations can be viewed that more interest in achieving levels of the authentic leadership and the $\mathrm{OBC}$ by enhancing the high levels of the organizational citizenship behavior in the researched companies which leads to enhance the positive effect for the authentic leadership practices in the organizational citizenship behavior in the researched companies. Never the less, gives more interest in the positive effect for the authentic leadership in the employees' commitment in the researched companies. In addition to that authentic leadership directly influence organizational citizenship behavior. Also, this study has several practical implications. First, we found a positive effect of authentic leadership on employees' OCB. As leadership plays a significant role in nurturing and boosting employee's attitudes and behaviors in the workplace. Companies should focus more on leadership behavior because it's affect employees' commitment and their productivity.

\section{References}

Ahmad, I., \& Zafar, M. A. (2018). Impact of psychological contract fulfillment on organizational citizenship behavior: Mediating role of perceived organizational support. International Journal of Contemporary Hospitality Management, 30(2), 1001-1015.

Al Omari, Ghassan, I. (2010).Characteristics of the leader according to Farabi perspective A comparative study. Egyptian Journal of Commercial Studies, Mansoura University, Faculty of Commerce, Egypt,4(34),253-287.

Al Sahi AL Zaabi, M. S., Ahmad, K. Z., \& Hossan, C. (2016). Authentic leadership, work engagement and organizational citizenship behaviors in petroleum company. International Journal of Productivity and Performance Management, 65(6), 811-830.

Ali, N., Mehmud, S., Baloch, Q., \& Usman, M. (2010). Impact of organizational justice on organizational citizenship behavior .of bankers of NWFP Pakistan (an empirical evidence). Interdisciplinary J Contemporary Research Business, 2, 111-117.

Allen, N. J., \& Meyer, J. P. (1990). The measurement and antecedents of affective, continuance and normative commitment to the organization. Journal of occupational psychology, 63(1), 1-18.

Anderson, K. B. (2016). Let me tell you a story: An exploration of the compliance-gaining effects of narrative identities in online crowdfunding textual appeals. State University of New York at Buffalo.

Ceri-Booms, M. (2010). An empirical study on transactional and authentic leaders: Exploring the mediating role of trust in leader on organizational identification.

Fox, S., \& Spector, P. (2008). Organizational citizenship behavior checklist (OCB-C). Layola University Chicago, USA.

Holtom, B. C., \& Sekiguchi, T. (2018). 21 Exploring the Relationship Between Job Embeddedness and Organizational Citizenship Behavior. The Oxford Handbook of Organizational Citizenship Behavior, 371. 
Insights, H. (2018). Hofstede Cultural Dimensions-Compare Countries: Retrieved January.

Nofal, I. M., \& Yusof, Z. M. (2016). Taxonomy Framework Of ERP Success Usage In Smes in Middle East Region. Journal of Theoretical \& Applied Information Technology, 86(3).

Joo, B.-K., \& Jo, S. J. (2017). The effects of perceived authentic leadership and core selfevaluations on organizational citizenship behavior: The role of psychological empowerment as a partial mediator. Leadership \& Organization Development Journal, 38(3), 463-481.

Khan, S. K., \& Rashid, M. Z. A. (2012). The Mediating Effect of Organizational Commitment in the Organizational Culture, Leadership and Organizational Justice Relationship with Organizational Citizenship Behavior: A Study of Academicians in Private Higher Learning Institutions in Malaysia. International Journal of Business and Social Science, 3(8).

Leroy, H., Palanski, M. E., \& Simons, T. (2012). Authentic leadership and behavioral integrity as drivers of follower commitment and performance. Journal of Business Ethics, 107(3), 255264.

Nofal, M. I. M., \& Yusof, Z. M. (2016). Conceptual model of enterprise resource planning and business intelligence systems usage. International Journal of Business Information Systems, 21(2), 178-194.

Peus, C., Wesche, J. S., Streicher, B., Braun, S., \& Frey, D. (2012). Authentic leadership: An empirical test of its antecedents, consequences, and mediating mechanisms. Journal of Business Ethics, 107(3), 331-348.

Shin, Y., Kim, M. S., Choi, J. N., Kim, M., \& Oh, W.-K. (2017). Does leader-follower regulatory fit matter? The role of regulatory fit in followers' organizational citizenship behavior. Journal of management, 43(4), 1211-1233.

Sosik, J. J., \& Jung, D. (2018). Full range leadership development: Pathways for people, profit, and planet: Routledge.

Stephen, P., Robbins, J., \& Timothy, A. (2017). Essentials of Organizational Behavior Plus Pearson Mylab Management with Pearson Etext, Global... Edition. Pearson Education Limited.

Walumbwa, F. O., Avolio, B. J., Gardner, W. L., Wernsing, T. S., \& Peterson, S. J. (2008). Authentic leadership: Development and validation of a theory-based measure. Journal of management, 34(1), 89-126.

Zhang, H., Everett, A. M., Elkin, G., \& Cone, M. H. (2012). Authentic leadership theory development: Theorizing on Chinese philosophy. Asia Pacific Business Review, 18(4), 587605. 